evidence of actual peritoncal invasion. Screral glands along the lesser curvaturo aro slightly cnlarged.

"Histelogically the tumour is a carcinoma of great collularity. In general the structure is spheroidal-celled ("encephaloid cancer'), but there is occasional acinar formation, and in places there is an abundant fibrous stroma. The tumour tissue has corimpletely penetrated the muscular coat over large areas, but nowhere is there a cancer-cell-free sclerolic mass indicative of pro-existing simple ulecration. Many nerve fibres are enbedded in the surface layers of the growth subserosally, where there are also some touch-corpuscles in close relation to it. Three lymph glands examined microscopically show extensive invasion."

On November 1st, 1987, I admitted this man to the Leeds Goneral Infirmary for investigation, as $I$ was curious to find out, if I could, how he had compensated for the complete absence of his stomach. At this time he lad gained about 1 st. in weight, was feeling fit, and eating. ordinary food, though slowly and in small quantitios. If he ate hurriedly or large amounts he felt distended and uncomfortable; howrer, he soon became humgry again. He had a craving for sugar and salt.

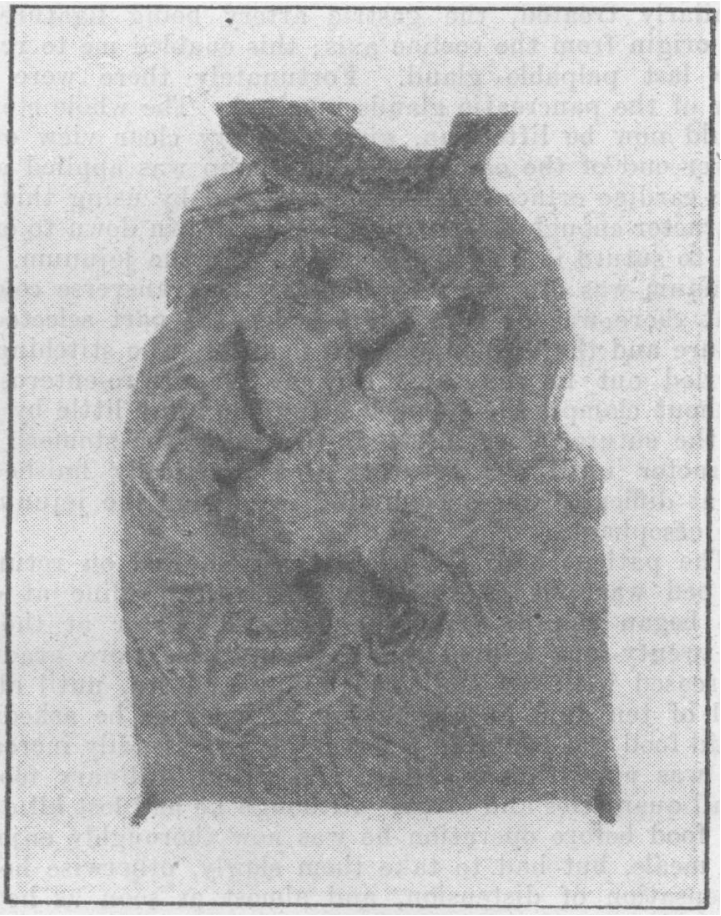

FiG. 1.- Showing the extent of the growth after laying open

The following results were obtained from various investigations, and I wish to express my thanks to Dr. Scargill, radiologist at the Leeds General Infirmary, and to Dr. Foweather and Dr. Hartfall, pathologists at the same institution, for their valuablo help in this respect.

T-ray Report, November sid, 192\%

1. A solid cachet was given. This passed straight into the jejunum; no delay at the anastomosis.

2. Fluid meal. This floods the upper small intestine at once; none is seen to pass backwards into the duodenum.

3. Four hours after giving the barium meal, all the barium is in the lower ileum.

4. Six hours after giving the barium meal, caccum filled; some still in the lower ileum (normal findings).

Blood Examination, Novcmber $2 n d, 192 \%$.

The blood count showed red cells 4,500,000 per c.mm., leucocytes 2,900 per c.mm., haemoglobin 76 per cent., colour index 0.84 .

Film: The red cells show slight variation in size and shape, but they stain well and evenly. Tho leucocytes show nothing for special comment beyond leucopenia.

Differential count: Eosinophil polymorphs 1 per cent., neutrophils 59.5 per cent., large mononuclears 5 per cent., Jymphocytes 34.5 per cent.

Biood sugar : 0.11 per cent. (normal 0.08 to 0.12 per cent.).

Blood cholesterol : 15 per cent.

ijea nitrogen: $19.6 \mathrm{mg}$. per $100 \mathrm{c.cm}$. blood (normal 10 to $20 \mathrm{mg}$.).

$\mathrm{CO}_{2}$ combining power : $57.5 \mathrm{c.cm}$. of $\mathrm{CO}_{2}$ bound as bicarbonate by $100 \mathrm{c.cm}$. of plasma (normal 60 to $70 \mathrm{c.cm}$.)
The saliva on Norenuber 2nd, 1927, showed alkalinity equivalent to 0.08 per cent. sodium carbonate (normal 0.08 to 0.1 per cent.).

On November 9th an eighteen-hour calture of faeces showed growth of $B$. coli; no pathogenic organisms were isolated; bile salts present. Total solid matter $40.7 \mathrm{per}$ cent. of dried faeces containing: fatty acids as soaps 17.3 per cent. free fatty acids 16.3 16.3 per cent., neutral fats 7.1 per cent. of dry facces. The facces contained 17.07 per cent. of dry matter. Fat-splitting appcars normal, but there is some deficiency in absorption of the split fat. Microscopic examination showed some undigested musele fibres
present, apparently in greater number than usual. Undigested vegetable material was also present. Tho urine on the samo date was normal.

An attcmpt was made to recover some of the contents of the jejunum after giving a test meal on the lines of the usual gastric test meal; it was found impossible to get sufficient for examination, I assume because of the rapid passage onward of the food.

I think this case is worthy of publication as the number of cases of successful complete gastrectomy for carcinoma of the stomach is very small. It is remarkable how efficient has been the compensation for total absence of the stomach. Six months after operation, apart from slight anaemia and lencopenia and a little deficiency in fat-splitting, there seems to be no noticeable alteration in the functions of his various systems so far as these can be determined. Possibly the fact that ho consumed large quantities of dilute hydrochloric acid at and between meals is partly responsible. It was found impossible to get him to continue this after he had returned to work.

It is now about eighteen months since the operation, and he is apparently quite fit and able to do reasonably haril work, and enjoys his food. He is free from anvthing which would suggest recurrence, and shows no sign of anaemia, though a blood examination has not been made since last November.

\section{CYSTICERCOSIS OF THE BRAIN :} WITH REPORT OH A CASE.

BY

\section{W. BROUGHTON-ALCOCK, M.B.CAxtab, D.C.Mr.S.(PATH.), MINISTRY OF PENSIONS ;}

W. E. STEVENSON, M.B., B.S.DurH., MEDICAL SUPERINTENDENT, MINISTRY OF PENSIONS HOSPITAL, YAGHUIL; AND

C. WORSTER-DROUGHT, M.A., M.D.Cantab., M.R.C.P., PHYSICIAN, WEST END HOSPITAL FOR DISEASES OF THE NERYOUS SISTEM AND METROPOLITAN HOSPITAL, AND NEUROLOGIST, MINISTRY OF PENSIONS.

(IVith Special Plate.)

Cisticercus cellulosac is rarely met with in this country, and, so far as we can ascertain, the following case is the only one for many years that has come to necropsy in England.

\section{Description of Case.}

History.-The patient enlisted in the army in June, 1918, at the age of 18, and proceeded to India in 1919. In July, 1921, ho developed enteric fever, which was complicated by thrombosis of the right leg. In June, 1922, tho vision of his left eyo became rapidly impaired (vision $6 / 60$ ), and a report states " atrophy of the retina duc to retinitis"; but it is admilted in a note in the following mouth (July) that "the diagnosis at present is in the follow " present is an er to havo attributed to an embolus of the retinal artery, but a further report in October, 1923, states "left vitreous occupied by mass of vascularized fibrous tissue." Eventually the cyo was enucleated at the Royal London Ophthalmic Hospital on July 26th, 1924. Dr. H. Coverdale, from the records of this hospital, kindly informs us that the left eye showed ciliary injection, old keratitis punctata, posterior synechiae, and cataract, with no pcrception of light. The right eye was normal. Unfortunately the pathological notes are missing. In view of his subsequent history, however, it is practically cortain that tho eyo was affected by cysticercus. is practically certain that the evo was affected by cysticercus. In April, India. The fits recurred from time to time at variable intervals; he would have as many as seven in twenty-four hours, but might; be free for as long as six weeks; they were both diurnal and nocturnal.

Dcseription of Fit.-A warning usually occurred with loss of power in either hand or in the right leg; unconsciousness followed and during the attack he frequently bit his tongue and passed urine. The fit was invariably followed by scvere headache, and occasionally by paresis of the right arm lasting up to half an hour. After a series of seven fits he once had complete loss of power in 


the left arm and hand lasting three days, with gradual recovery. Occasionally he would vomit within twenty-four hours of the fit. In November, 1925, two definite attacks were witnessed by a resident physician in hospital; they were both Jacksonian in type, afiecting the right side of the face, followed by a period of unconsciousness, but no generalized convulsion. During the latter part sciousness, but no generalized convulsion. During the latter part
of 1927 the fits became more frequent, and his speech became offected.

P'hysical Signs (March 27th, 1928).-Cranial nerves: Right pupil sluggish to light; left eye absent. "No nystagmus. Slight rightsided facial weakness. Speech of "bulbar" trpe. No muscular weakness of limbs. Deep reflexes brisk, but equal. Right plantar flexor; left doubtful. No definite inco-ordination. Mentally he was very dull and able to give but little account of himself. was very dull and able to give but little account of himself. During the next two weeks he complained continuously of headsuddenly on April 11th, aged 28.

\section{Pathological Description.}

The right half of the brain and a crst attached to the dura mater were received for detailed examination.

On inspection of the cortex forty rounded white nodules, in size from that of a lentil to that of a pea, and lying both in sulci and in the middle of gyri, are seen irregularly embedded in the cortex, and in the greater number over the vertex of the hemisphere. On the mesial surface similar cysts are irregularly scattered, but are less numerous than on the outer surface. There is no macroscopic evidence of pus or inflammatory redness. nor of softening in the brain substance surrounding the cysts; and none of the cysts seen shows calcification. They are firm to the touch, giving one an impression rather than a thought of tuberous sclerosis.

It may here be added that at necropsy cysts were visible on the dura of the vertex as soon as the skull cap was removed. The one sent with the brain is from among those found in the basal membranes. The left hemisphere was cut up, examined, and then thrown away. It is reported to have been similarly infected.

On section of the right cerebral hemisphere a few crsts are seen scattered about the cerebral substance, and appear almost exclusively confined to the grey matter; when present in white matter they are at the border of gres matter (Fig. 1). A few cysts occur in the mesial portion of the occipital and frontal lobe and in the basal ganglia there are relatively as many as in the cortex; they are present in both the lenticular nucleus and optic thalamus. In the pons, on section, a single cyst the size of a small pea is found lying nearer the ventral than the dorsal surface, about two-thirds the distance from the superior limit of the pons to the medulla. None are seen in the medulla. A- far as we can estimate the number of cysts in the half-brain is about 100 .

On the cortex of the cerebellum are three cysts, each the size of a lentil, while on section one cyst is secn deep in the substance of the organ.

No cyst in the cutancous and muscular structures or other organs was detected at necropsy; the spinal cord was not examined. In the old clinical notes no mention is made of Turmin solium occurring in the intestine.

On section the cysts in the brain substance show the interior of the cystic envelope or adventitious membrane to be smooth and glistening, and to contain little if any clear fluid. Attached within this envelope at one site are much smaller, clear, brownish, circular cysts, varying in size, and rounded or ovoid in shape: some appear as swollen grains of rice covered with a trownish membrane, others that are larger are more balloon-like, and membrane, others that are larger are more balloon-like, and
contain more fluid, the invaginated scolex lying like a grain of rice within, or partly within and partly without, the bailoon-like membrane or cysticercus outer wall (Fig. 2).

By direct examination typical chasacters of the scolex with its hooklets and four suckers are seen (Fig. 3). An interesting feature in two of the cysticerci examined microscopically is the presence of numerous ovoid and round bodies, some of the larger with modified centres, of all shades of colour from clear to quite black. These bodies are not ova, but we understand are quite calcium substance, which forms gas on the addition of acid. Ther lic especially in and towards the invaginated head of the scolex. In other details the cysticerci resemble descriptions given in many textbooks. The cystic envelope or adventitious membrane is adherent to and formed from the surrounding brain tissue. As our microscopical findings do not conform to that which we understand is the more typical histological structure of this envelope we may report that sections of three complete crst were made, and each shows a very heavy cell infiltration around the ronnective tissue stroma and extending for a short distance into brain substance; and, when a free vessel is prisent a little be roud brain substance; and, when a free vessel is present a little beyond
this, perivascular infiltration is apparent. The majority of infiltrathion cells are plasma cells with fewer small round cells, and a fair number of endothelial cells are also present, while in one section two giant cells with massed nuclei are seen. The characteristic cosinophilia is present in one envelope only, and red blood ceills are extremely rare. In one section a small vessel on the external border of the envelope shows a moderate degree of endarteritis. In one envelope the sclerotic tissue is much developed and has a pronounced cell infiltration external to this. In this cyst only an occasional chalk body is seen in the crsticercus. but a line of cuboid hacmatoxylin staining bodies are present.

(Our acknowledgements are due to Dr. C. Lovell and $\mathrm{Mr}$. Crowe of Bethlem Royal Hospital Pathological Laboratory for their kind assistance in preparing the photomicrographs appearing as Fig. 8
and Fig. 3.)

\section{Commextany.}

Cysticercus ccllulosae is exressively rare in this country; it occurs chiefly in eastern Europe, India, and South America. Its occurrence in man has apparently beeti known since 1558, and there is scarcely an organ in which the parasite has not been oberved. The brain is one of the situations most commonly affected. Thus in 155 cases of crsticercosis compiled by stiles, ${ }^{2}$ the brain was involved in 117, the muscles in 32, the lieart in 9, the subcutancous tissnes in 5, and the liver in 2. In Dressel's series ${ }^{3}$ of 87 cases the brain was affected in 72 and the muscles in 13; while K. Miiller, in 36 cases. found the parasite 21 times in the hrain, 12 times in the muscles. and thrice in the heart. In Vongien's series" the following was the incidence of the organs involved: eves and adjoining structure 46 per cent., nerrous system 40.9 per cent., skin and cellular tissues 6.32 per rent., muscles 3.7 per cent., and other organs 3.2 per cent. Titu Vasilu (1921), in an analysis of 330 cases of resticercosis of the nervous system, described the brain and meninges as affected in 279, cerchlar ventricles in 41, pons and medulla in 5, and the spinal cord in 5 cases.

In a prolonged experience of men disabled following temporary military service we have only once met with a case of crsticercosis, and in this case the cysts were in the subcutaneous tisues. Licut.-Colonel MacArthur, R.A.M.C.. lowerer, informs us that he has diagnosed rlinically 5 cases of crsticercus infection with definite signs of central nervou retem involvement amongst soldiers whose scrvice in India and other places abroad has been more prolonged.

E. J. H. Roth' records a remarkable case in a man, aged 44, who had suffered from rpileptiform fits for ten years. The patient had sored with the army in India from 1908 to 1911. and came under shservation in 1926 on account of pain in the left knee-joint of about five years' duration. with a discharging sinus which had appeared two month previonsly. Cysticercus infection was diagnosed from the radiogram of the knee-joint; scattered throughout the muscles around the joint were numerous opaque and ovoid bodies which were undoubtedly of the nature of calcifications. Further radiograms showed a similar condition in nearly every part, but with the main grouping of the calcified nodules on the extremities as far down as the ankles and wrists. The diagnosis of cysticercosis wa ronfinmed by excision and microscopical examination of one of the crsts from the right forearm.

C. J. Hill Aitken ${ }^{8}$ has recently recorded the case of a roung man who had served in the army and complatined of severe headache, diplopia, and "fits." Some small subcutaneous nolules were discovered, which on examination and patholigical examination proved to be cysticerci.

Since ron Graefe first demonstrated the pressence of crsticercus in the vitreous of the eve, several similar cases have heen recorded, and there can be no doubt that in the present rase the enucleated eve showed the first s.mplomof crsticereus infection.

When the hrain is affereted the symptoms are usually rague and weneral, and ras: have been said to simulate hysteria, epilepsy lerebral tumour, basal meningitis, and general paralysis. Transient tonic spasms and antomatic morements have her'n described by Wollenberg. In Roth's case, radiograms showed at least three calcified crsts ling in the pia mater: one was localized in the middle of the motor area on the left side. In the present case the main srmptoms appear to have been those of foral epileper. hut with no constancy in the particular site affected.

Mental impairment is also a common synutom in rexchal crsticercosis, and usually comsists of a simple weakness of intellect ; conditions of excitcment, confusion, and hallucination, howerer, have all heon deseribed. F. Hattmann" has recorded serere disturbance of orientation, impairment of stereoscopic vision, and a form of mind hlindness. Involvement of the fourth rentricle he creticercus appoars to be frequent, and in this situation may lead to sudden death. Cases have been recorded by Hammer, Meyer, Rothmanti, and others, while Burns, Oppenheim. Gerhandt, and Henneberg'to have described combinations of simptonis arising from involrement of the cerebellmm and medulla. 
In the present case no involvement of the medulla was found. Extensive fibrous meningitis resembling gummatous basilar meningitis has also been described by Askanazy ${ }^{11}$ Rosenblatl, 12 Henneberg, ${ }^{10}$ and others. As far as is known, the cysts are very little toxic, although it appears that prrexia vccurred at the onset of infection or early in the course of a ciss of disseminated cysticercosis described by Major R. 1.riest'" in 1926.

The case we record proved fatal after nearly six years of svmptoms; but the parasites, especially when localized in the eve or brain, may live for long periods, very rare ascs being noted up to twenty years (Küchenmeister, Ruth-1rinoff, l'feifer, and others).

\section{REFEREXCES.}

Rümler: Ubs. Iletl., liii, 32 (quoted by Fantham, Stephens, and Theobsid, The 1nimal Parasites of Man, London, 1916).

Stiles : Qunted by W. Osler, Principles and Practice of Medicine.

Fantham, Stephens, and Theobald: The Animal Parasites of Man, London, 1915, p. 324 .

4 losgien: Quoted by Brumpt, Précis de Parasitologie, Paris, 1927.

$\checkmark$ Titu V'asilu: Quoted by Brumpt.

MacArthur, Li uat.-Colonel W. P.: Personal communication.

Roth, E. J. H. : British Medical Journal, 1926, ii, 470.

Aitken, C. J. Itill: Ibid., 1928, i, 943.

ITartmann. F. : Q inted by Oppenheim, Text-book of Nervous Diseases, Edin., 1911, ii, 942.

10 Henneberg: Charite-Annalen, vol. $\mathrm{xxx}$

"Askanazy" : Zirgler's Beitr., vol, vii.

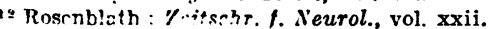

13 Pricst, Mlujor R. : Eritish Medical Journal, 1926, ii, 471.

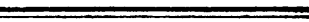

\section{A CASE OF PNEUMOCONIOSIS.}

Result of the Inhalation of Asbestos Dust.

BY

H. E. SHILER, M.B., Сн.B., D.P.H.Самв., ASSISTANT IIEDICAL OFFICER, PUBLIC HEALTH DEPARTMENT, GLASGOW.

(With Special Plate.)

THe asbestos industry has been in existence for over two thousand years, and it is remarkable that the possibility of damage to the lungs, arising from the inhalation of dust during its manufacturing process, has not been investigated until within comparatively recent years. Very few cases of pnenmoconiosis due to asbestos dust have heen recorded in medical literature, and for this reason the notes on the following case may be of some interest.

The first recorded case was that reported by the late Dr. Montague Murray of Charing Cross Hospital in 1900. $N_{0}$ other case was reported, and the inference that asbestos dust might the the cause of an extensive pulmonary fibrosis was lost sight of for some time. In $1824^{1}$ and $1927^{2} \mathrm{Dr}$. W. E. Cooke published his exhaustive reports on another rase, and described in detail the pathological changes and his "curious bodies," which are apparently a unique feature of the microscopical picture. This stimulated other investigations, and Simson ${ }^{3}$ has reported similar findings in workers employed in the crushing of asbestos rock, as apart from the manufa: turing processes. In most of the cases hitherto reported the extensive fibrosis has been asscciated either with pulmonary tuberculosis or an unresolved pneumonia, and there has always been the slight doubt as to whether the inhalation of asbestos dust was the primary cause of the fibrosis.

The paticnt, a man aged 40 years, was sent for an opinion of his chest condition to the tuberculosis dispensary. The question of tuberculosis was raised as a consequence of his complaint of cough and brenthlessness, combined with loss of weight and lassitude, extending over a period of several months.

Previous History. - There was no history of tuberculosis in the f omily. No history could be elicited of any illness in early life which might have led to a pulmonary fibrosis, and, apart from the symptoms whinh he considered to be associated with his occupation as an asbestos worker, he has had no other illnesses.

Occupation.- When a boy he had worked for a very short period in a glass works. Thereafter, for a period of twenty-two rints, he has been associated with the asbestos industry. During this period he has been employed in the various processes of asbestos work: for four and a half years be worked at a carding machine, which is considered the dustiest part of the work; for seven and a half vears at the weaving of asbestos cloth, and for the remainder of the period at the manufacture of the millboard. The various processes differ considerably in their degree of dustiness, and therefore in the amount of asbestos dust inhaled by the various types of workers. As, however, a number of different processes, evolving a varying amount of dust, may be different processes, evolving a varying amount of dust, may be
carried out in the same room, lie dust produced at any one carried out in the same room, tie dust produced at any one
process may affect workers at another process. It will be noted that this man must have worked in the asbestos industry for a period during which less importance was paid to the prevention of dust than it the present time.

History of Present Illness.-The patient has had a cough from within a few months of starting work at asbestos, but he states that this was "from the throat," and appeared to have been purely the result of dust irritation. Within recent years the cough has increased in severity, and there has been a little sputum first thing in the morning. The first symptom to cause anxiety was breathlessness, which developed five years ago, and this has become accentuated since then. His general condition has remained satisfactory, and his particular symptoms were not sufficiently severe to interfere with his employment until a few months ago. At this time he complained of lassitude, loss of months ago. At this time he complained of lassitude, loss of
weight, frequent night sweatings, and an occasional slight aching of the left shoulder. On no occasion has there been haemoptysis.

Notes on Examination.- $-\mathrm{He}$ is a spare-built man; weight 7 st. $11 \mathrm{lb}$; temperature, pulse, and respirations within normal 7imits. No obvious dyspnoea noted on examin tion. Cyanosis of limits. No obvious dyspnoea noted on examin tion. Cyanosis of
lips and cheeks, but not a marked feature. Well-marked finger clubbing noticed by the patient for at least two years. Sputum scanty; and of a mucoid nature. Tubercle bacillus absent on frequent examination.

Examination of Chcst.-Inspection showed expansion to be poor generally (one inch by measurement); there was hypertrophy of the extraordinary muscles of respiration; the supraclavicular fossae were markedly hollowed; the heart apex beat was in the fifth intercostal space within the nipple line. The percussion note was flattened throughout; there was relative dullness over the right upper lobe, both in front and behind. On auscultation the respiratory murmur was diminished generally, and of a harsh quality over the right upper lobe anteriorly and posteriorly; quality over the right upper lobe anteriorly and posteriorly, with fine pleural friction at both bases.

Othcr Systcms.-Examination of other systems was negative.

$X$-Ray Examination. - The radiogram of the chest shows a fine mottling of a silicotic type throughout both lungs, more marked on the right side and at both bases, with indication of a definite fibrosis, especially on the right side. (See special plate.)

Progrcss.-The patient was admitted to hospital for observation, and has now been an in-patient for six months. During this period his general condition has improved considerably, and he has gained over 1 st. in weight. The cyanosis which had been noted on first examination has to a great extent disappeared, but there is still some evidence on the cheeks and lips. The cough, which is now manifestly less troublesome, is still present, and there is a scanty mucoid sputum. Physical examination of the chest reveals no new feature apart from the absence of the chest reveals no new feature apart from the absence of
bronchitic sounds. The temperature and pulse remained within normal limits during the period of observation and treatment normal lim
in hospital.

\section{Conclusion.}

There seems little doubt that this is a definite case of pulmonary fibrosis, the result of the inhalation of asbestos dust. The recent development of symptoms of toxaemia, associated with long-standing pulmonary symptoms, was at first suggestive of a chronic pulmonary tuberculosis with an acute exacerbation. However, the physical signs, the persistent absence of the tubercle bacillus in the sputum, and the maintenance of temperaturo and pulse within normal limits demanded further investigation. The typical radiographic features (signs more marked in the basal portions of the lungs) and his long period of employment with asbestos point definitely in the direction of a fibrosis of occupational origin, especially as there is neither a history of other illnesses in childhood or adolescence to support a more common cause of pulmonary fibrosis, nor does this correlation of history, symptoms, and physical signs occur in these latter cases. Toxaemic symptoms in the absence of a tuberculous affection are of special interest; whether they are the result of the absorption of some constituent of the ashestos rock or not is a point which requires further investigation.

\section{RFFERENCES.}

2 Cooke, W. E. : Fibrosis of the Lungs due to the Inhalation of Asbestos Dust, British Medical Journal, 1924, ii, 147.

2 Cooke, W. E., Stuart McDonald, and Sir T. Oliver : Pulmonary Asbestosis, British Medical Journal, 1927, ii, 1024. 3 Simson, F. W.: Pulmonary Asbestosis in South Africa, British Mcdical Jourkal, 10:3, i, 895 . 